\title{
Does The Classroom Delivery Method Make A Difference?
}

Esther Bunn, Stephen F. Austin State University, USA Mary Fischer, University of Texas at Tyler, USA

Treba Marsh, Stephen F. Austin State University, USA

\begin{abstract}
This study seeks to determine if a difference exists in student performance and participation between an online and face-to-face Accounting Intermediate I class taught by the same professor. Even though students self-selected which course section to enroll, no significant difference was found to exist between the delivery method of the two courses based on the student's major field of study, gender, and whether or not they commuted to class. No significant difference is found between the assessments of the two class sections' membership except the students' course performance. Contrary to prior research, the students enrolled in the online sections did not perform as well as the face-to-face students. This study supports prior research which finds that online class support videos or other materials must be kept to ten minutes or less to retain students' attention.
\end{abstract}

Keywords: Face-To-Face Accounting Class; Distance Learning; Online Accounting Class

\section{INTRODUCTION}<smiles>c1ccccc1</smiles>

ver the past thirty years, state funding for public higher education has lost its stride in meeting the rising educational costs. Researchers find that higher education has covered the shortfall by raising tuition, reducing payroll, cutting financial aid, and using technology; i.e., online course delivery (Ehrenberg, 2006; Lyall \& Sell, 2006, Weerts \& Ronca, 2012). A revolution is underway to reduce costs and move away from the one-size-meets-all education with technology allowing classes to be taught at different speeds. Universities are not only using the Internet to reduce instruction costs, but also to expand geographic reach and enhance capabilities. Arbaugh (2000) reports that over two-thirds of accredited colleges and universities in the United States (US) offer online courses. Nelson (2013) indicates the number of AACSB-accredited schools offering one or more of their degree programs fully online have grown by nearly $43 \%$ over the past five years. The question of quality, comparability, and difference between online and face-to-face (FTF) classrooms become more relevant as the proliferation of online courses and programs increase and pressure for budget cuts in higher education continue.

\section{Traditional Face-To-Face Classroom}

The traditional FTF delivery system for higher education has been a classroom setting with the professor giving a lecture with illustrations and projected slides while students listen, write notes, and ask questions. Personal interactions between the professor and student, or among students, which lead to personal transformation are viewed as the essential learning environment.

There are numerous advantages to the FTF method. A study by Nemanich et al. (2009) concludes that students perform better and find more enjoyment in the FTF than online. FTF courses with communication and feedback between instructor, student and among students reflect a more collaborative and cooperative environment (Leidner \& Jarvenpaa, 1995). Communication in FTF courses often includes nonverbal cues which may reduce cognitive effort and ambiguity making the course more receptive and enhancing content understanding and retention (Koch et al., 2007). Additionally, Wilson and Fowler (2005) suggest that cooperative peer learning may lead to higher interest in the course and comprehension. However, innovations in educational delivery challenge this paradigm. 


\section{Distance Learning}

Distance learning through correspondence courses has been delivered by higher education institutions for over fifty years. Correspondence courses gave way to the use of closed circuit television course delivery about 25 years ago. Generally, these methods were not perceived as providing the same learning impact as the FTF method. The changing demographics of students, new visual acquired skill sets (thanks to television and video games), and new educational competitors are driving the adoption of educational delivery systems that bridge the time and placebound constraints of traditional FTF courses.

College enrollments have grown rapidly in recent years constraining classroom space utilization. From 2001-02 to 2011-12, the number of full-time undergraduate students increased from 8.6 million to 11.8 million and part-time undergraduate students increased from 5.5 million to 6.8 million (College Board, 2012). The U.S. Department of Education (2009) reports that enrollment in for-credit online courses increased by 107 percent from 1997 to 1998 at institutions offering associate degrees. At four-year institutions during the same period, online undergraduate course enrollments increased 121 percent while graduate online course enrollments increased 79 percent.

During the time period of 2002 to 2012, public higher education support diminished due to state appropriations to public colleges and universities declining by 3\% in fiscal year 2011 and by another $11 \%$ in fiscal year 2012, after adjusting for inflation (College Board, 2012; Weerts \& Ronca, 2012). The increasing enrollment and reductions in public support for higher education force academic administrators to find new ways to reduce instruction costs. These administrators look to online classes as a means of providing lower course delivery cost to a larger student body, avoiding building classrooms and hiring additional faculty (Chubb \& Moe, 2012).

Merisotis and Phipps' (1999) review of 40 research papers analyzing distance learning find that the majority of the studies conclude that distance-learning courses (regardless of the technology used) compared favorably with FTF instruction and enjoyed high student satisfaction. Distance learning effectiveness is found to be comparable to FTF classes (Jones et al., 2005; Carrol \& Burke, 2010). Conversely, student performance is found to favor FTF (Priluck, 2004; Terry et al., 2001). Arbaugh and Rau (2007) find that graduate student learning and satisfaction with online courses differ across the curriculum. Although, studies that focus solely on overall effectiveness (Gagne \& Sheperd, 2001; Vamosi et al., 2004) report mixed results.

However, Merisotis and Phipps (1999) point out several research shortcomings including not controlling for extraneous variables, not using randomly selected subjects, and questionable validity and reliability of instruments used to measure student outcomes. The U. S. Department of Education (2010) compares research of FTF versus online learning and reports that online or hybrid learning modules appear to be as effective as conventional classroom instruction.

In an effort to determine if comparison results in teaching methods was course dependent, several business courses were analyzed. A comparison of an online and a FTF section of a Principles of Management by Neuhauser (2002) found no significant difference, although the online group's averages were slightly higher. Navarro and Shoemaker (2000) compare the performance of students enrolled in an online introductory economics course to those enrolled in a FTF class. They find that those enrolled in online courses learn as well, or better than, those enrolled in FTF courses. Gagne and Shepherd (2001) analyze the performance of two sections of an introductory graduate level accounting course and find the performance of students in an online course are similar to the performance of students in the FTF course. These results are consistent with those found by the U. S. Department of Education (2010) analysis which reports that differences in subject matter did not affect the outcomes. These findings are in contrast to Arbaugh and Rau (2007) who report student learning and satisfaction with online courses differ across the curriculum.

\section{Mixed Results}

These studies suggest there is no clear evidence of which delivery system is more efficient and effective. Students in FTF classes may be more comfortable with the personal interaction, whereas those studying online have 
the flexibility and convenience of studying at their own pace, in their own space, and at times that are convenient for them. However, students accustomed to learning in an instructor-centered environment may have more difficulty when enrolled in a student-centered online environment. In addition, online classes do not provide for the interaction between the instructor and students and among students found in FTF classrooms, and considered by many to be essential to learning. To mediate these issues, Carrol and Burke (2010, p. 70) proposed that the online delivery mode should develop online team projects and the FTF courses should consider using online content delivery application.

\section{This Study}

Studies comparing FTF student performance to online course performance typically have analyzed students in urban or metropolitan higher education institutions. This study seeks to determine if a difference exists in student performance and participation between an online and FTF course taught at a rural university.

\section{Participants}

This study uses information obtained from two sections of Accounting Intermediate I taught by the same professor in the 2012 Fall Semester at a rural university. The Intermediate Accounting I class is required for all accounting majors and minors. No other major requires Intermediate Accounting, although finance and computer science students frequently take the course because they perceive that it will be advantageous in their professional careers. Students self-selected enrollment into either the online class or the traditional FTF on-campus lecture class.

The same assurance of learning assessment measures were administered to the FTF and online section. Activities to enhance deep learning also were provided in each section, including the utilization of prior learning as a foundation of new knowledge, couching support materials in a way to learn new situations, and providing timely reinforcements. Neither class had an enrollment cap to manage class size. The FTF section met twice a week and the online section met asynchronously. The FTF class lectures were videotaped, transcribed, and posted to a secure server and made available to students in the online section no later than the following class day. To ensure student anonymity, all identifying information was eliminated from the collected data.

\section{Variables of Interest}

Several variables were of interest in this study. Items that measure performance - final grade, grade point average (GPA) and student anticipated grade - were collected. Demographic items that describe the student - gender, academic major and address relative to campus - were obtained. Finally, information relative to instruction satisfaction - instructor presents information effectively, questions are encouraged, provides students with help on problems and fair/impartial grading - were analyzed. No student information, other than class section, was associated with the collected information to ensure anonymity.

\section{RESULTS AND DISCUSSION}

The two sections of Intermediate I had a total enrollment of 61 students of which 50 self-selected the oncampus section. Student demographic information was analyzed to determine if significant differences exist among students enrolled in the two sections. Table 1 displays that no significant differences exist based on the students' major, gender, or their accessibility to the classroom. Based upon the students' major and gender, student composition was comparable in each of the two class sections. It is interesting to note that 18 percent of those students who selected the traditional FTF class delivery on campus were commuting a distance of 50 miles or more. Although the analysis indicates that no significant difference exists between the two groups, apparently these students selecting to enroll in the campus course desired the FTF interaction to the extent that they drove at least one hour to attend class. 
Table 1: Demographic Information

\begin{tabular}{|c|c|c|}
\hline & Traditional & Online \\
\hline \multicolumn{3}{|l|}{ By Major } \\
\hline Accounting & $82.0 \%$ & $81.8 \%$ \\
\hline Nonaccounting & $18.0 \%$ & $18.2 \%$ \\
\hline \multicolumn{3}{|l|}{ Chi-Square $1.406 \alpha=.924$} \\
\hline \multicolumn{3}{|l|}{ By Gender } \\
\hline Male & $48.0 \%$ & $45.5 \%$ \\
\hline Female & $52.0 \%$ & $54.5 \%$ \\
\hline \multicolumn{3}{|l|}{ Chi-Square $.023 \alpha=.878$} \\
\hline \multicolumn{3}{|l|}{ Commuting Distance } \\
\hline Live on campus & $36.0 \%$ & $27.3 \%$ \\
\hline Live in town & $22.0 \%$ & $9.1 \%$ \\
\hline Live within 50 miles & $24.0 \%$ & $54.5 \%$ \\
\hline Live beyond 50 miles & $18.0 \%$ & $9.1 \%$ \\
\hline Chi-Square $4.251 \quad \alpha=.236$ & & \\
\hline
\end{tabular}

Students in both the FTF and online class were enrolled in an average of 12.5 semester hours of course work. Given this finding, the students will need to enroll in summer classes to complete the 150 hours to apply for the CPA exam within five years.

The performance analysis (see Table 2) found the more significant differences between the two student groups. The students in the traditional FTF class self-reported the higher earned GPA and expected to earn a higher grade in the class than did the students who selected to enroll in the online section. None of the students who enrolled in the online class reported having a GPA greater than 3.49 on a 4-point scale. They also did not expect to earn higher than a $\mathrm{B}$ in the class and a fifth of the online students did not expect to earn a passing $\mathrm{C}$ grade. As the analysis reveals, none of the online students earned an A or B and almost two-thirds of the students enrolled in the online class did not earn credit for the course.

Table 2: Performance

\begin{tabular}{|c|c|c|}
\hline & Traditional & Online \\
\hline \multicolumn{3}{|l|}{ Self Reported GPA } \\
\hline 3.5 to 4.0 & $14.0 \%$ & $0.0 \%$ \\
\hline 3.0 to 3.49 & $26.0 \%$ & $27.3 \%$ \\
\hline 2.5 to 2.99 & $28.0 \%$ & $18.2 \%$ \\
\hline 2.0 to 2.49 & $24.0 \%$ & $18.2 \%$ \\
\hline Below 2.0 & $8.0 \%$ & $36.3 \%$ \\
\hline \multicolumn{3}{|l|}{ Chi-Square $7.541 \alpha=.056$} \\
\hline \multicolumn{3}{|l|}{ Anticipated Grade } \\
\hline A & $38.1 \%$ & $0.0 \%$ \\
\hline $\mathrm{B}$ & $40.0 \%$ & $60.0 \%$ \\
\hline $\mathrm{C}$ & $19.0 \%$ & $20.0 \%$ \\
\hline Below $\mathrm{C}$ no credit & $2.9 \%$ & $20.0 \%$ \\
\hline \multicolumn{3}{|l|}{ Chi-Square $16.328 \alpha=.003$} \\
\hline \multicolumn{3}{|l|}{ Course Grade } \\
\hline A & $34.0 \%$ & $0.0 \%$ \\
\hline $\mathrm{B}$ & $22.0 \%$ & $0.0 \%$ \\
\hline $\mathrm{C}$ & $18.0 \%$ & $36.4 \%$ \\
\hline Below C no credit & $26.0 \%$ & $63.6 \%$ \\
\hline Chi-Square $12.497 \alpha=.014$ & & \\
\hline
\end{tabular}


The online student performance was significantly different from the traditional FTF students across all three measures - self-reported GPA, expected course grade, and earned course grade.

The evaluation analysis (see Table 3) finds that the online students' opinions were similar to those in the traditional FTF, with the exception of their evaluation of the instructor encouraging questions.

Table 3: Evaluation

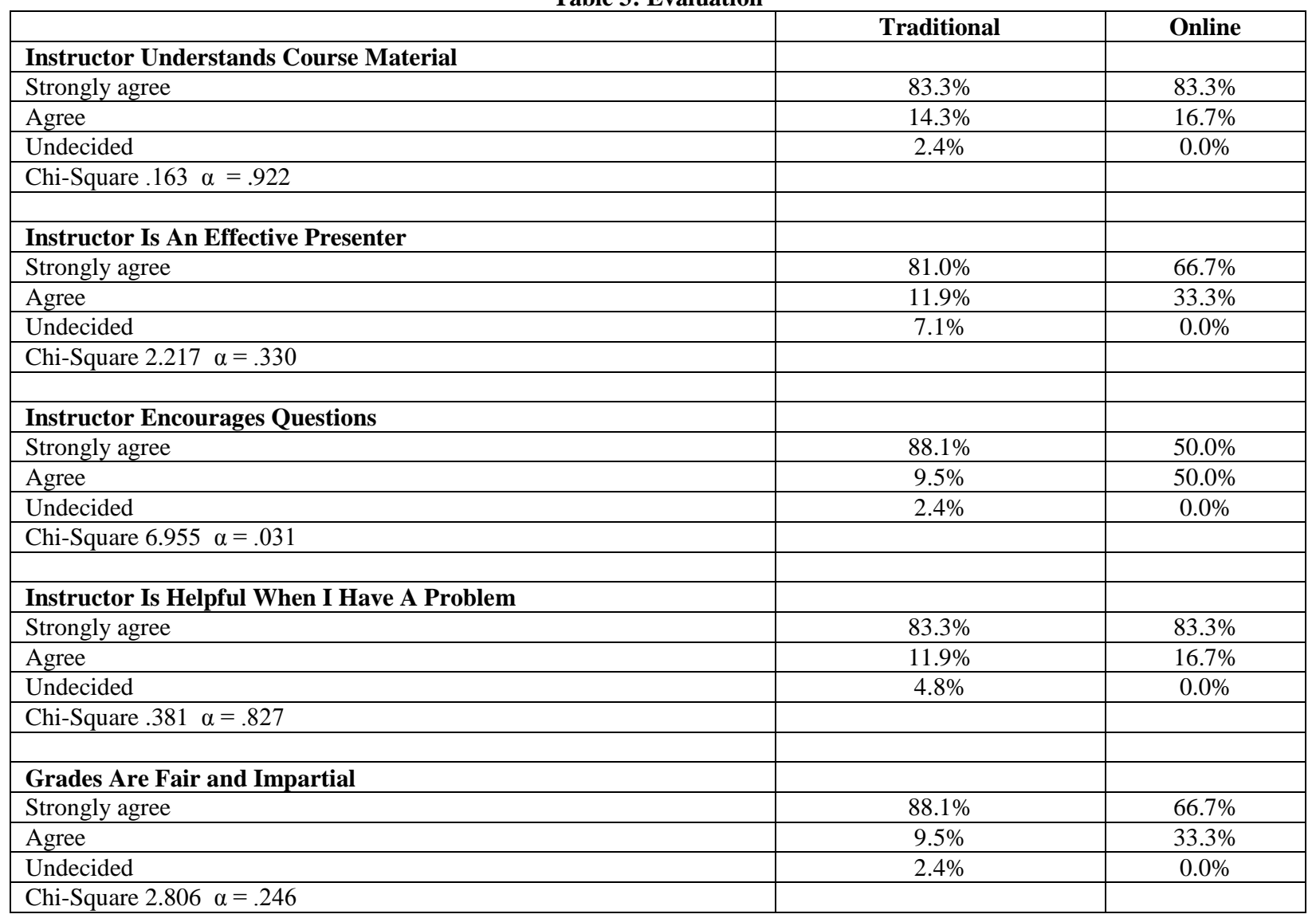

This difference is interesting as both groups of students believed that the instructor was very helpful when they had a problem. In fact, the response to that question was very similar to the students' opinions concerning the instructor's command of the material.

With the significant opinion difference of the students concerning the lack of encouragement to ask questions, the unsolicited comments provided by the students on their evaluations were reviewed. All the online students expressed their pleasure that the course was offered online and that recordings of the FTF class lectures were provided. The online students did not like the limited attempts on homework assignments and exam questions, whereas the traditional FTF students did not mention those concerns at all. The online students reported that the class was very difficult to navigate and often temperamental. Given the online students' concerns, it is possible that technology was the confounding problem rather than the instructor delivery.

These results have implication for faculty and administrators who consider which classes, if any, to offer online as delivery method does appear to matter. Where online classes are scheduled, activities to enhance student and instructor interaction are warranted. For example, a mix of the online and FTF, or hybrid delivery mode, has been shown to be effective in bridging the gap between solely online courses and traditional FTF classes. Ginns and Ellis (2007) and Chen and Jones (2007) find that offering a mix of online and on-campus class meetings enables the instructor to clarify confusing concepts for students in upper-level courses. Another blending technique would be for 
the on-campus classes to employ technology-based learning activities, such as online homework, quizzes, and discussion boards, to enhance learning activities. Jones and Chen (2008) find that courses delivered primarily online are more productive and result in greater student satisfaction when four carefully managed on-campus class meetings are scheduled. This study finds that students suffer as a result of completing an upper-level accounting class solely online when compared with students completing the same course in a traditional FTF mode.

\section{LIMITATIONS}

There are three limitations concerning the results of this study. First, random assignments and experimental manipulation is not possible for a study of this type that controls for instruction differences by utilizing the same instructor for all sections. Should the scheduled delivery time or days of the week configuration not be appropriate for the student who desires to enroll in the traditional FTF section of the course, their only option would be to defer enrolling in the class until a later semester. This decision could well impact the student's degree plan and graduation.

Learning styles assessment would have provided much more information about the students enrolled in each of the two courses. With that information, faculty could develop specific activities to enhance the students' performance. For example, short video clips, web-based u-tube explanation of accounting functions, email communications, and other activities could be utilized to develop and retain students' interest and learning motivation.

Another limitation is the failure to gather more extensive student information. For example, information about the students' number of credit hours enrolled, age, family obligations, and hours worked would have been rich data to use as obligation control factors. Thus, this study was unable to analyze the impact of this information on learning outcomes or on online students' selection of class section. Future studies should include these variables as additional controls.

\section{CONCLUSION}

This study compares two sections of the same course - one taught FTF and one taught online. Even though students self-selected the course to enroll, no significant difference was found to exist between the two courses in the student's major field of study, gender, and whether or not they commuted to class. Although none of the students in the study withdrew from their respective course, three students in each of the two classes stopped out; that is, they stopped participating or attending class but did not drop the class, which resulted in a failing grade.

No significant differences appeared between the assessments of the two groups of students with the exception of the course performance. The major activities of the course were comparable for the online and FTF students.

Contrary to prior research findings, the online students did not perform as high as the FTF students. Although the online students had the opportunity to observe the FTF class lectures and discussion, few online students took advantage of the material. This finding supports research that indicates to be effective, online support videos or other materials should be kept to no more than 10 minutes to retain the student's attention.

The results of this study must not be over generalized. The study demonstrates that equivalent learning activities can be delivered effectively for online and FTF classes. However, care must be taken in sharing the FTF activities with the online students so as to attain or maintain the online student's attention or desire to participate in the online postings and discussion boards. Faculty should be encouraged to use FTF methodologies and materials as a foundation for online courses and use media materials to enhance effective online learning.

\section{AUTHOR INFORMATION}

Esther Bunn, MPA, Lecturer, Gerald W. Schlief School of Accountancy, Stephen F. Austin State University, Nacogdoches, Texas 75962. Her research interests include accounting education and financial accounting. E-mail: estherbunn@sfasu.edu 
Mary Fischer, Ph.D., Professor, College of Business \& Technology, University of Texas at Tyler, Texas 75799. Her research interests include financial accounting, nonprofit and government organizations, auditing, and accounting education. E-mail: MFischer@uttyler.edu

Treba Marsh, DBA, Professor, Gerald W. Schlief School of Accountancy, Stephen F. Austin State University, Nacogdoches, Texas 75962. Her research interests include state and local public finance, financial accounting, internal controls, and public budgeting. E-mail: tmarsh@ @fasu.edu (Corresponding author)

\section{REFERENCES}

1. Arbaugh, J. B. (2000). Virtual classroom characteristics and student satisfaction with Internet-based MBA courses. Journal of Management Education, 24, 32-54.

2. Arbaugh, J. B., \& Rau, B. (2007). A study of disciplinary, structural, and behavioral effects in online MBA courses. Decision Science Journal of Innovative Education, 5(1), 65-95.

3. Carrol, N., \& Burke, M. (2010). Learning effectiveness using difference teaching modalities. American Journal of Business Education, 3(12), 65-76.

4. Chen, C., \& Jones, K. (2007). Blended learning versus traditional classroom settings: Assessing effectiveness and student perceptions in an MBA accounting course. The Journal of Educators Online, 4(1), 1-15.

5. Chubb, J. E., \& Moe, T. M. (2012). Higher education's online revolution. The Wall Street Journal. May 30.

6. CollegeBoard Advocacy \& Policy Center. (2012). Trends in college pricing. Retrieved from www.collegeboard.org

7. Ehrenberg, R. G. (2006). What's happening to public higher education? Portsmouth, NH: Greenwood Press.

8. Gagne, M., \& Shepherd, M. (2001). Distance learning in accounting. T.H.E. Journal, 28(9), 58-65.

9. Ginns, P., \& Ellis, R. (2007). Quality in blended learning: Exploring the relationships between online and face-to-face teaching and learning. Internet and Higher Education, 10, 53-64.

10. Jones, K., \& Chen, C. (2008). Blended learning in a graduate accounting course: Student satisfaction and course design issues. The Accounting Educators' Journal, 18, 15-28.

11. Jones, K., Colky, D., \& Cyboran, V. (2005) E-learning takes the lead: An empirical investigation of learner differences in online and classroom delivery. Performance Improvement Quarterly, 18(4), 5-8.

12. Koch, N., Verville, J., \& Garza, V. (2007). Media naturalness and online learning: Findings supporting both the significant- and no-significant perspectives. Decisions Sciences Journal of Innovative Education, 5, 333-355.

13. Lyall, K. C., \& Sell, K. R (2006). The de facto privatization of American higher education. Change, 38(1), 6-13.

14. Leidner, D. E., \& Jarvenpaa, S. L. (1995). The use of information technology to enhance management school education: A theoretical view. MIS Quarterly, 19, 265-291.

15. Merisotis, J. P., \& Phipps, R. A. (1999). What's the difference? Outcomes of distance vs. traditional classroom-based learning. Change, May/June, 13-17.

16. Navarro, P., \& Shoemaker, J. (2000). Performance and perceptions of distance learners in cyberspace. The American Journal of Distance Education, 14(2), 15-35.

17. Nelson, C. (2013). Growth in accessibility of AACSB-accredited online degrees. Retrieved 2/17/13 from aacsbblogs.typepad.com/dataandresearch/2013/01/growth-in-accessibility-of-aacsb

18. Nemanich, L., Banks, M., \& Vera, D. (2009). Enhancing knowledge transfer in classroom versus online settings: The interplay among instructor, student, content, and context. Decision Sciences Journal of Innovation Education, 7(1), 123-148.

19. Neuhauser, C. (2002). Learning style and effectiveness of online and face-to-face instruction. The American Journal of Distance Education, 16(2), 99-113.

20. Priluck, R. (2004). Web-assisted courses for business education: An examination of two sections of principles of marketing. Journal of Marketing Education, 26(2), 161-173.

21. Terry, N., Owens, J., \& Macy, A. (2001). Student performance in the virtual versus traditional classroom. Journal of the Academy of Business Education, 2(1), 1-4.

22. U. S. Department of Education (2009). The condition of education. New York, NY: USDOE. 
23. U. S. Department of Education. (2010). Evaluation of evidence-based practices in online learning: A metaanalysis and review of online learning studies. Washington, D.C.: USDOE.

24. Vamosi. A., Perce, B. G., \& Slotkin, M. H. (2004). Distance learning in an accounting principles course Student satisfaction and perceptions of efficacy. Journal of Education for Business, 79(6), 360-366.

25. Weerts, D. J., \& Ronca, J. M. (2012). Understanding differences in state support for higher education across states, sectors and institutions: A Longitudinal study. The Journal of Higher Education, 83(2), 155183.

26. Wilson, K., \& Fowler, J. (2005). Assessing the impact of learning environments on students' approaches to learning comparing conventional and action learning designs. Assessment and Evaluation in Higher Education, 30, 87-101. 